\title{
Effect Of Diazepam On The Prenatal Development Of Neuropil Of The Purkinje Cell Layer Of The Cerebellar Cortex Of The Rats Embryo (Electron Microscope Study)
}

\author{
Lotfy Sayed**, Mamdoh Ghalli**, Essam El-Din Abdelhady* \\ Ola Abdelhamid*** and Reda Awadalla* \\ Anatomy Department*, Histology Department** Faculty of Medicine, Al-Azhar University \\ Anatomy Department*** Faculty of Medicine, Al-Azhar University (Girls)
}

\begin{abstract}
Diazepam is one of the most widely used sedative hypnotic agents, and many women take this drug during pregnancy.

The purpose of this study was to investigate the effects of diazepam on the development of the neuropil of the Purkinje cell layer of the cerebellar cortex.

Twenty female pregnant rats were used in this study. The rats were divided into two groups, the first group (5 rats) was used as control group and the second group (15 rats) were given 10 $\mathrm{mg} / \mathrm{kg} /$ day of diazepam orally and sacrificed at $15^{\text {th }}, 20^{\text {th }}, 25^{\text {th }}$ days of pregnancy. It was difficult to differentiate between the dendrites and the axonal knobs at $15^{\text {th }}$ day of pregnancy. As age advanced, the dendrites were swollen with absence of cytoplasmic organelles or contained few free ribosomes and immature mitochondria. The observed axonal knobs contained ill-defined synaptic vesicles. Immature axo-dendritic synapses were recognized on the $15^{\text {th }}$ and $20^{\text {th }}$ days of pregnancy, while on the $25^{\text {th }}$ days of pregnancy symmetrical axo-dendritic synapses were recognized. From this study, it appears that the exposure to diazepam causes marked changes on prenatal development of neuropil of the Purkinje cell layer of the cerebellar cortex.
\end{abstract}

\section{Aim of the work}

The aim of the work was to study the effects of diazepam on the development of the neuropil of Purkinje cell layer of the cerebellar cortex.

\section{Introduction}

Diazepam is the most important sedative hypnotic drug used, it is given orally, intramuscular and intravenous, and it is absorbed very rapidly into the blood following oral or intramuscular administration and concentrated in the nervous tissues. The therapeutic dose is $5 \mathrm{mg}$ twice daily (Katzyng 2001). It is metabolized in the liver and excreted via the kidneys (Chouinard G. 1999 and Avallone et al 2002).It causes sedation and hypnosis, it is also used in anesthesia, convulsion and relaxation of the muscles (Walsh and Schweitzer 1999 and Musavi \& Kakkar 2003).

Recently, the morphology of the cerebellar neurons and their intercortical connections is being intensively studied. The cerebellar cortex has a limited number

of neuron types and a stereotyped pattern of architectural organization which is characterized by its structural uniformity in the whole extension of the cortical mantle (Cormack 2001). The cerebellar cortex is composed of three layers; the molecular cell layer, Purkinje cell layer and granular layer (Gartner and Hiatt 2000)

The germinal zone, which surrounds the $4^{\text {th }}$ ventricle, gives rise to the cells of Purkinje, Golgi, and the cerebellar glia (William 1995). The other neurons of the cerebellar cortex such as the star cells, basket cells, granular cells, and other glial elements are derived from the original germinal cells in the rhombic heights (Altman, 1972).

Purkinje cell layer: the Purkinje cells are large Golgi type I neurons. They are 
flask-shaped and are arranged in a single layer in a plane transverse to the folium, the dendrites of these cells are seen to pass into the molecular layer where they undergo profuse branching. The primary and secondary branches are smooth and subsequent branches are covered by short, thick dendritic spines. It has been shown that the spines form synaptic contacts with the parallel fibers derived from the granule cell axons. (Cormack 2001). At the base of the Purkinje cell, the axon arises and passes through the granular layer to enter the white matter. On entering the white matter, the axon acquires a myelin sheath and it terminates by snapping with cells of one of the intracerebellar nuclei. Collateral branches of the Purkinje axon make synaptic contacts with the dendrites of basket and stellate cells of the granular layer in the same area or in distant folia. A few of the Purkinje cell axons pass directly to end in the vestibular nuclei of the brain stem. (Snell 1997)

Neuropil was a term given to the areas of the central nervous system neurons that most of the synaptic junctions occurred (Peters, 1970). Between the nests of the cell stomata in the developing Purkinje cell layer, there are areas of cell processes in various stages of differentiation which are identified as dendrites. The dendrites are not very numerous and contain mitochondria, free ribosomes, some elements of the rough and smooth endoplasmic reticulum, neurofilaments and microtubules (Doulazmi, 2002) Large dendritic profiles more rich in organelles are identified as dendritic trunks, while smaller dendritic profiles having fewer organelles are considered as dendrilic tips. A second component of the neuropil is the dendritic spine which is recognized along the course of some dendrites. The dendritic spine has a short slender stem with expanded tip. Some of these spines might contain spine apparatus (Valsecchi et al 1993). A third component of the neuropil consists of numerous elements of varying size containing numerous vesicles $300-600 \mathrm{~A}^{\mathrm{o}}$ in diameter. They are axonal knobs which contain round and/or flat synaptic vesicles (.Schaal et al 1985).
The axo-dendritic synapses are classified into:

1-Gray's type I (symmetrical synapse): It has a wide synaptic cleft and shows a prominent post-synaptic thickening.

2- Gray's type II (asymmetrical synapse): it has a narrow cleft without postsynaptic thickening

The cerebellar syndrome is the most neurological alteration frequently resulting from diazepam. This has raised the idea of the existence of a marked vulnerability of the cerebellum to the action of diazepam. For this reason, in the present work, we analyzed the pathological effect of diazepam on the neuropil of the Purkinje cell layer of the cerebellar cortex of the rat embryo (William 1995).

\section{Material and Methods}

Twenty female pregnant rats were used in this study. They were divided into two groups. Rat of the first group (5 rats) was used as a control group. Rats of this group were given 0.1 c.c. physiological saline orally by gastric tube. The rats of the second group (15 rats) were given diazepam in a dose equal to $10 \mathrm{mg} / \mathrm{kg} /$ day orally by gastric tube.

Both groups were kept in metal cages with proper ventilation and humidity. All the rats were sacrificed on the $15^{\text {th }}, 20^{\text {th }}$, and $25^{\text {th }}$ days of treatment respectively. The cerebella were extracted from the embryo and cut into slices $1 \mu \mathrm{m}$ thick. The slices of the cerebella of both control and treated groups were fixed in $1 \%$ gluteraldehyde and osmic tetroxide. Then the specimens were prepared for the electron microscope study.

\section{Results}

\section{1- Control Group:}

On the $15^{\text {th }}$ day of treatment, the neuropil of the Purkinje cell layer contained small dendritic profiles and profiles of axonal knobs. The dendritic profiles had a relatively clear dendroplasm. Profiles of axonal knobs were seen with ill-defined synaptic vesicles. Immature axo-dendritic contacts were observed but without marked synaptic thickening (Fig.1). 
On the $20^{\text {th }}$ day of treatment, the neuropil of the Purkinje cell layer contained dendrites, dendritic spines and axonal knobs. The dendritic profiles contained mitochondria and neurofilaments (Fig. 3). The dendritic spines were recognized at this age, (Fig.3), Axonal knobs containing synaptic vesicles were clearly identified. Both symmetrical and asymmetrical axo-dendritic synapses were recognized (Fig. 2 and 3 )

On the $25^{\text {th }}$ day of treatment, the neuropil of the Purkinje cell layer contained dendrites, dendritic spines and axonal knobs. The primary dendrites of the Purkinje cell neurons arose from the parent cell body. The dendrites exhibited the same organelles that were found in the soma cytoplasm (Fig. 4). Longitudinal sections of the secondary and terminal parts of these dendrites contained only mitochondria, neurofilaments (Fig.5), and micro tubules (Fig. 6). Dendritic spines were recognized along the course of some of the dendrites. The spines had a short slender stem with expanded tip (Figs. 5, 6, $7 \&$ \&), some of these spine might show spine apparatus (Fig. 6 \& 9). The axonal knobs could be identified in the neuropil of the Purkinje cell layer.

\section{2- Treated group:}

In the neuropil of the treated Purkinje cell layer on the $15^{\text {th }}$ day of treatment, it was difficult to differentiate between the axons and dendrites. The axons and dendrites separated from each other by wide cleft-like spaces. The axo-dendritic contacts were easily identified (Fig. 10).

On the $20^{\text {th }}$ day of treatment, the neuropil showed swollen dendritic profiles with absence of cytoplasmic organelles. The dendrites and axonal terminals were separated by cleft-like synaptic spaces. Dendritic spines were not clearly identified. Axonal knobs were observed with illdefined synaptic vesicles. Immature axodendritic synapses were observed without synaptic thickening (Fig. 11)

On the $25^{\text {th }}$ day of treatment, the dendritic profiles were swollen and empty or contained few free ribosomes and immature mitochondria. Neurofilaments and microtubules were not identified. Dendritic spines could not be observed. The axonal knobs were observed containing ill-defined synaptic vesicles. Rounded and flat vesicles were not identified. Axo-dendritic synapses were recognized as symmetrical synaptic thickening. Asymmetrical axo-dendritic synapses were not observed (Fig. 12).

(Fig.1) Electron micrograph of the neuropil of Purkinje cell layer of the cerebellum of 15-days control rat. The dendritic profiles (d) have a relatively clear dendroplasm. The axonal knobs (a) are with ill-defined synaptic vesicles. (X 80000)

(Fig-2) Electron micrograph of the neuropil of the Purkinje cell layer of the cerebellum of 20-days control rat. It shows dendrites of Purkinje cells (d). There are symmetrical (S) and asymmetrical (S+) types of axodendritic synapses, dendritic spine $(\mathrm{P})$ was noticed

(X64000)

(Fig.3) Electron micrograph of the neuropil of Purkinje cell layer of the cerebellum of 20-days control rat. It shows large dendrite (d) containing mitochondria (m) and neurofilaments (n). Dendritic spines (P) are present. Axonal knobs (a) containing synaptic vesicles are clearly identified. Both symmetrical (S) and asymmetrical $\left(\mathbf{S}^{+}\right)$axo-dendritic synapses are present.

(X80000)

(Fig.4) Electron micrograph of the Purkinje cell layer of the cerebellum of 25-days control rat. It shows a portion of the Purkinje cell nucleus (N) and its cytoplasm (C). The dendrites ( d ) also seen which are the similar to the soma cytoplasm. Notice the presence of axonal knobs (a).

(X 32000)

(Fig. 5) Electron micrograph of the neuropil of the Purkinje cell of the cerebellum of 25-days control rat shows large dendrite (d) having neurofilaments (n) and mitochondria (m). Dendritic Spine (P) with spine apparatus is seen. Axonal knobs with synaptic vesicles (a) are seen. Axo- 
dendritic synapses of symmetrical (S) and asymmetrical (S+) types are present.

(X160000)

(Fig 6) Electron micrograph of the neuropil of the Purkinje cell layer of the cerebellum of 25-days control rat. It shows Purkinje cell dendrites (d) containing mitochondria (m), neurofilaments (n) and microtubules (t).The dendritic spine arises from the dendrite (p).

(X 100000)

(Fig-7) Electron micrograph of the neuropil of the Purkinje cell layer of the cerebellum of 25-days control rat. It shows dendrites with the presence of a dendritic spine $(\mathrm{P})$, spine apparatus making synapse with an axonal knob (a) by symmetrical type. The axonal knobs (a) contain round synaptic vesicle and dense - core vesicle.

(X80000)

(Fig.8) Electron micrograph of the neuropil of the Purkinje cell layer of the cerebellum of 25-days control rat. It shows dendrite (d) surrounded by axonal knobs (a) with round synaptic vesicle (r) and flat synaptic vesicle (f)

(X80000)

(Fig.9) Electron micrograph of the neuropil of the Purkinje cell layer of the cerebellum of 25-days control rat. It

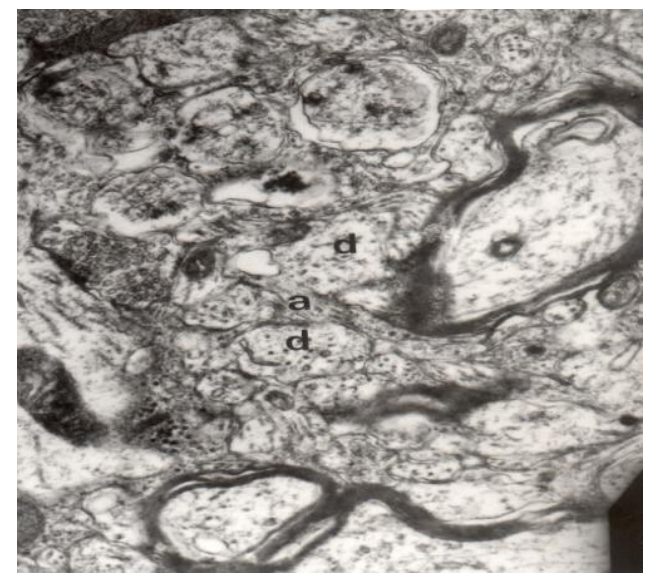

(Fig. 1) shows the presence of dendrite (d). The dendritic spines contact with axonal knobs by symmetrical (S) and asymmetrical $\left(\mathbf{S}^{+}\right)$types of synapses. The axonal knobs contain round (r) synaptic vesicles and dense core vesicles (v).

(X80000)

(Fig. 10) Electron micrograph neuropil of the Purkinje cell layer of the cerebellum of 15-days rats treated with diazepam It shows the profiles of terminal axon (a) and dendrite (d) without any organelles.

(X 80000)

(Fig.11) Electron micrograph of the neuropil of the Purkinje cell layer of the cerebellum of 20-days rats treated with diazepam. It shows swollen dendritic processes (d) with absence of cytoplasmic organelles. Axonal knobs (a) contain few ill-defined synaptic vesicles.

(X 80000)

(Fig.12) Electron micrograph of the neuropil of the Purkinje cell layer of the cerebellum of 25-days rats treated with diazepam. It shows empty dendritic processes (d) and axonal knobs (a) with ill-defined synaptic vesicles.

(X 80000)

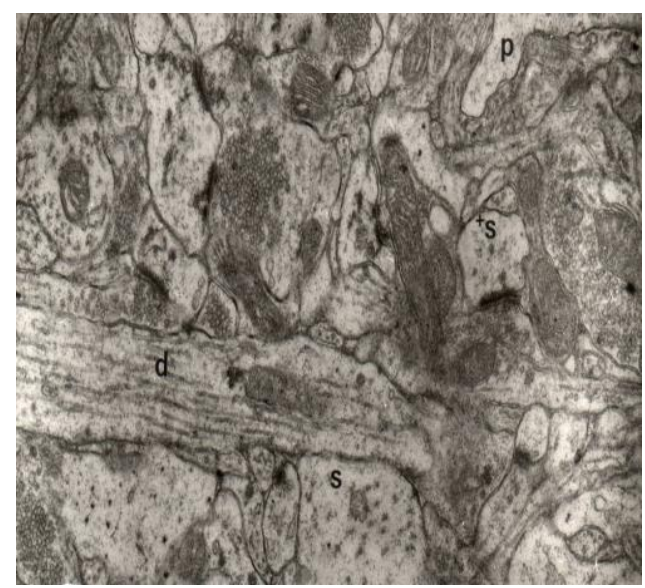

(Fig. 2) 


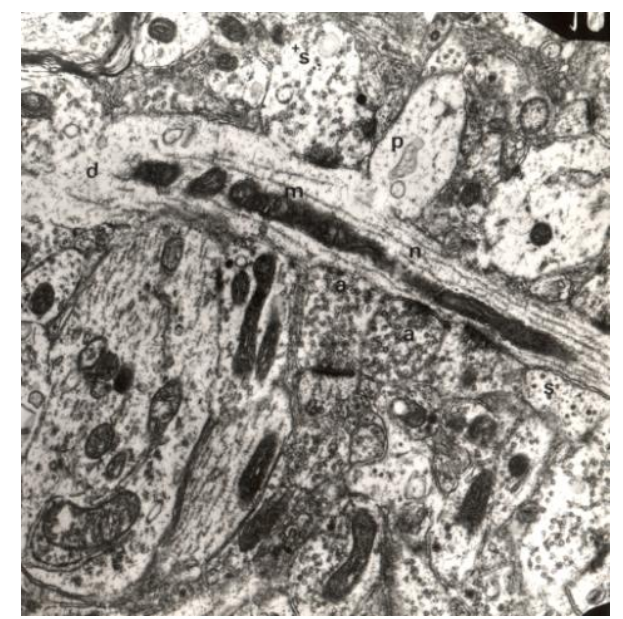

(Fig. 3)

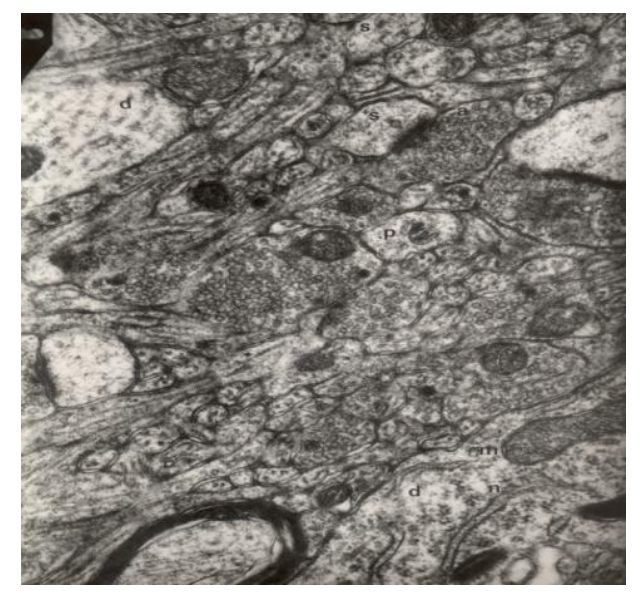

(Fig. 5)

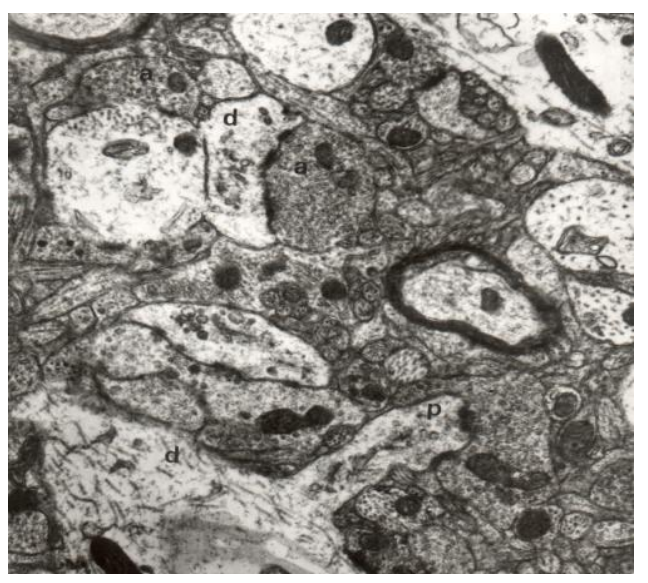

(Fig. 7)

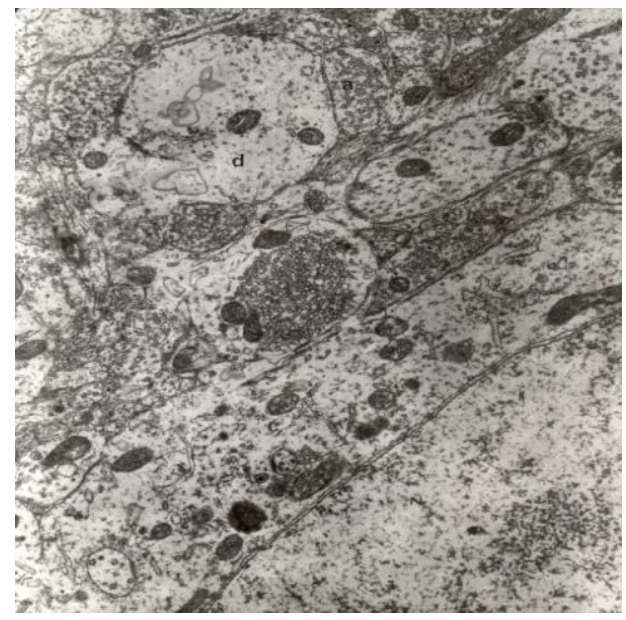

(Fig. 4)

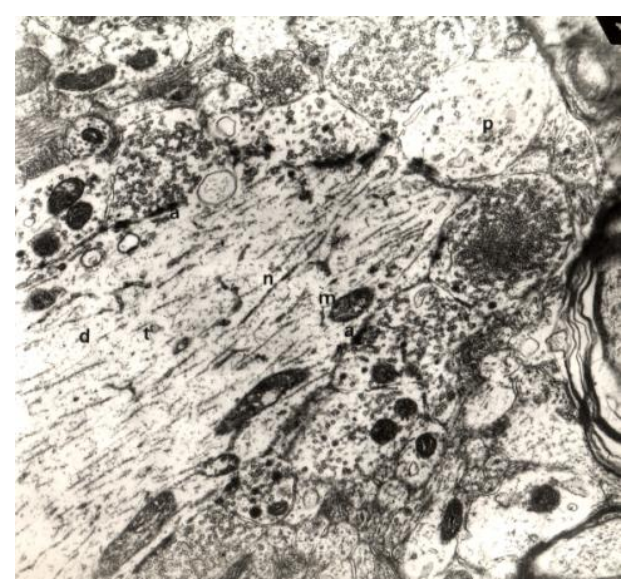

(Fig. 6)

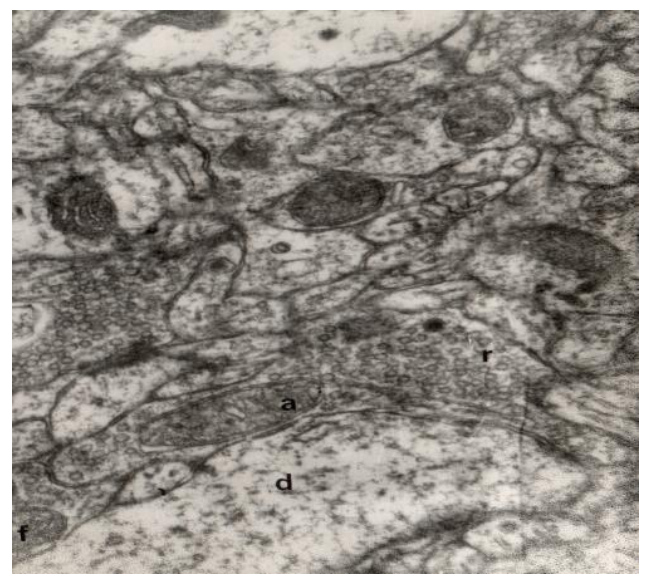

(Fig. 8) 


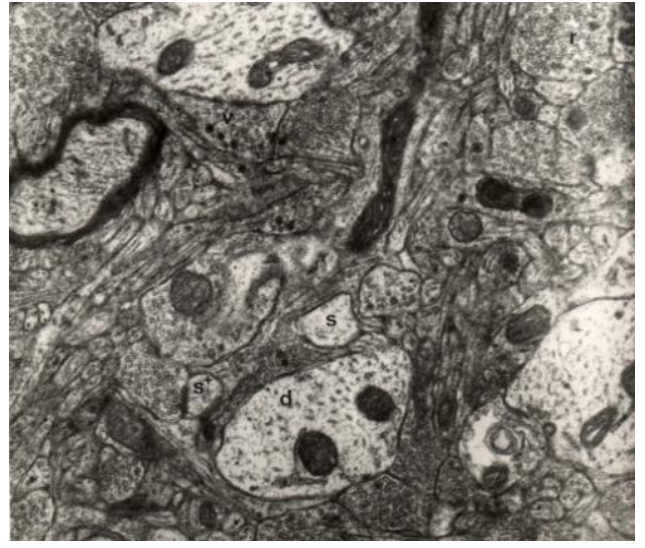

(Fig. 9)

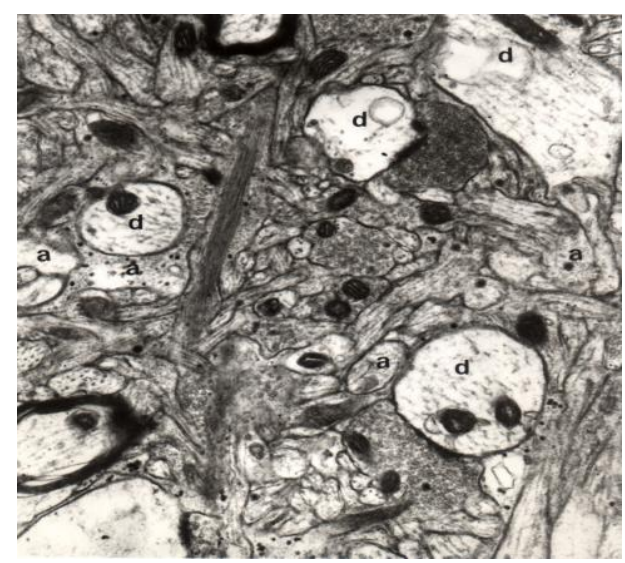

(Fig. 11)

\section{Discussion}

The cerebellum controls the equilibrium and is particularly affected by many hypnotics like diazepam. It is known that all the drugs used by human are able to produce tolerance; diazepam is one of the drugs which cause many changes on the cerebellum. The pathological changes following exposure to diazepam occurred more frequently in undifferentiated cells or during their process of differentiation. Also, the adverse action of diazepam was dependent on the neuronal age. Thus, our present study is to observe the possible effects of diazepam in different stages of cerebellar development of rat embryo.

The present data indicate that on the $15^{\text {th }}$ day of treatment, it was difficult to differentiate between the dendrites and the axonal knobs. As age advanced, the dendrites were swollen with absence of the cytoplasmic organelles or contained few free ribosomes and immature mitochondria.

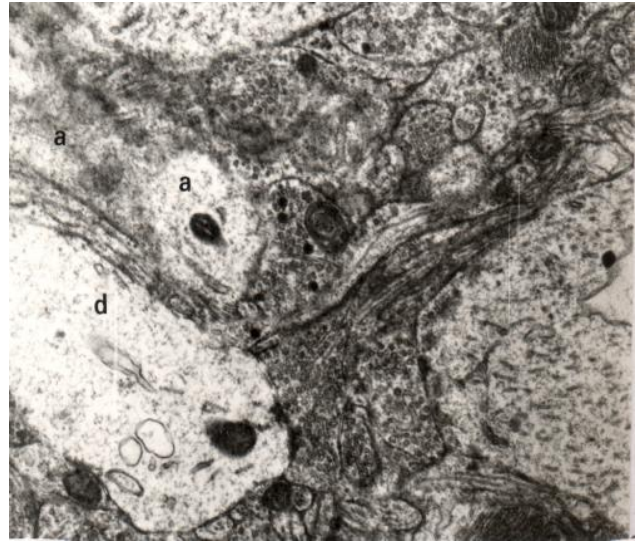

(Fig. 10)

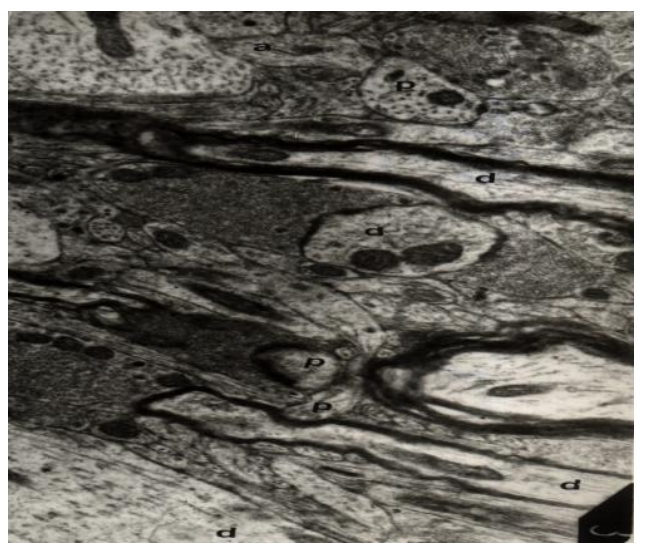

(Fig. 12)

The axonal knobs were observed containing ill-defined synaptic vesicles. Also on the $15^{\text {th }}$ and $20^{\text {th }}$ days of pregnancy, immature axo-dendritic synapses were observed, while on the $25^{\text {th }}$ days of pregnancy, axodendritic synapses of symmetrical type were recognized. These observations may be related to the accumulation of drug and the blood level of diazepam. The data are compatible with the results obtained from Gallager\& Mallorga \{1980), Westmoreland \& Bass (1971), Vorhees et al (1990) and Deluka et al (2002).

The findings of the present work confirm those of many workers who showed that the most striking changes in the structure of the rat cerebellum after administration of diazepam were observed in the synaptic buttons mainly in the Purkinje cell layer of the cerebellar cortex. The synapses affected were predominantly of symmetrical and asymmetrical types of 
axo-dendritic synapses with decreased number of the synaptic vesicle hypertrophy of the axonal terminal. Origuchi et al (1975), Desor et al (1978), Mennini et al (1984) and Schwartz et al (1985) showed that the Purkinje cell layer of the cerebellar cortex of the rat treated with diazepam showed numerous degeneration dendrites within the neuropil in the form of swollen dendritic profiles with clear dendroplasm or degenerated cytoplasmic organelles especially mitochondria. Early axonal injuries were also present, which contained ill-defined synaptic vesicles.

The results of this study on the effects of prenatal exposure to diazepam indicate that on the 20th day of treatment, the neuropil showed swollen dendritic profiles with absence of cytoplasmic organelles. The dendrites and axonal terminals were separated by cleft-like synaptic spaces. Dendritic spines were not clearly identified. Axonal knobs were observed with illdefined synaptic vesicles. Immature axodendritic synapses were observed without synaptic thickening. The results are compatible with behavioral observations of Dam (1972), Klotz (1979), Vaccarino et al (1983), Takeichi (1983) and Hevers \& Luddens (2002) who stated that the neuropil of Purkinje cell layer of the mouse cerebellum after prenatal and postnatal diazepam administration showed degenerative synaptic terminals and depletion of synaptic vesicles. Immature axo-somatic and axo-dendritic contacts were recognized as demonstrated by the electron microscope.

Our study showed that the histopathological alterations on the neuropil of the Purkinje cell layer of the cerebellar cortex of the mice due to effect of diazepam was in the form of deformed swollen dendritic profiles with clear dendroplasm or contained deformed and degenerated cytoplasmic organelles especially mitochondria with absence of other cytoplasmic organelles especially neurofilaments and microtubules. The axonal buttons were observed containing ill-defined synaptic vesicles with immature axo-dendritic contacts, but without synaptic thickening. These findings may be due to inhibition of neuronal growth factors. The result are in agreement with the result of Candy \& Martin (1979), Rotter \& Frostholm (1988), Marquez et al (1994) and Musavi \&Kakkar (2000) who studied the effect of diazepam on the neuropil of the Purkinje cell layer of the cerebellar cortex of the rat. They found degenerated swollen dendritic profiles with absence of the cytoplasmic organelles or contained few ribosomes and immature or degenerated mitochondria. Other cytoplasmic organelles of the dendroplasm as neurofilaments, microt-ubules, and endoplasmic reticulum were absent. Deformed axonal terminals with ill-defined synaptic vesicles were recognized

\section{References}

1. Altman J. (1972): Postnatal development of the cerebellar cortex in the rat. J. Comp. Neurol., 145: 353-398.

2. Avallone R, Cosenza F, Farina F, Baraldi C, Baraldi M. (2002): Extraction and purification from Ceratonia siliqua of compounds acting on central and peripheral benzodiazepine receptors. Fitoterapia. Aug; 73(5):390-6.

3. Candy JM, Martin IL. (1979): The postnatal development of the benzodiazepine receptor in the cerebral cortex and cerebellum of the rat. J Neurochem. Feb; 32(2):655-8. No abstract available.

4. Chouinard G (1999): Metabolism of anxiolytics and hypnotics. Benzo diazepins, buspirone and zolpiden. Cell Mol Neurobiology 19:533

5. Cormack H. David (2001): Essential Histology $2^{\text {nd }}$ edition chapter 9 nervous tissue and nervous system page 209-236. Lippincott Williams \&Wilkins

6. Dam M.(1972): The density and ultra structure of the Purkinje cells following diphenylhydantoin treatment in animals and man. Acta Neurol Scand Suppl. 49:3-65. No abstract available.

7. Deluka SR, Protic S, Vrbaski SR. (2002): Ganglioside a/b ratio in different rat brain regions following chronic diazepam treatment. Neurol Sci. Jun; 23(2):69-74.

8. Desor D, Royer RJ, Netter P, Guedenet JC, Faure G, Krafft B, Grignon G.(1978): [Effect of diphenylhydantoin administered during gestation and lactation on the motor development and cerebellar histology of the young rat]C R Seances Soc Biol Fil. 172 (6):1057-62. French. 
9. Doulazmi M, Hadj-Sahraoui N, Frederic F, Mariani J. (2002): Diminishing Purkinje cell populations in the cerebella of aging heterozygous Purkinje cell degeneration but not heterozygous nervous mice. J Neutrogena. Apr-Jun; 16(2):111-23.

10. Gallager DW, Mallorga P. (1980): Diphenylhydantoin: pre- and postnatal administration alters diazepam binding in developing rat cerebral cortex. Science. Apr 4; 208(4439):64-6.

11. Gartner P. Leslie and James L. Hiatt (2000): Color Atlas of Histology, nervous tissue, page 137-149

12. Hevers W, Luddens H (2002): Pharmacological heterogeneity of gammaaminobutyric acid receptors during development suggests distinct classes of rat cerebellar granule cells in situ. Neuropharmacology. Jan; 42(1):34-47. Katzyng G Bertram (2001): Basic \& Clinical pharmacology, Eight edition, Cha. 22, sedative - Hypnotic Drugs. Page 264280. Middle East edition. Lange Medical Books, Librairie duLiban, Mc Grow -Hill, Beirut, London

13. Klotz U. (1979): Effect of age on levels of diazepam in plasma and brain of rats. Naunyn Schmiedebergs Arch Pharmacology. Jun 18; 307(2):167-9.

14. Marquez-Orozco MC, Marquez-Orozco A, Gazca-Ramirez MV, AndradeMartinez R.(1994): Cerebellar ultra structural changes produced by diazepam. Proc West Pharmacology Soc.; 37:115-6. No abstract available.

15. Mennini T, Ceci A, Caccia S, Garattini S, Masturzo P, Salmona M.(1984): Diazepam increases membrane fluidity of rat hippocampus synaptosomes. FEBS Lett. Jul 23; 173(1):25

16. Musavi S, Kakkar P. (2000): Pro and antioxidant responses to repeated administration of diazepam in rat brain. Mol Cell Biochem. Mar; 206(1-2):97-103.

17. Musavi S, Kakkar P. (2003): Effect of diazepam treatment and its withdrawal on Pro/antioxidative processes in rat brain. Mol Cell Biochem. Mar; 245(1-2):51-6.

18. Origuchi Y, Nonaka I, Ueno T, Usuku G.(1975): Ultra structural changes in the cerebellum of young rats having received diphenylhydantoin during the embryonic stage. Kumamoto Med J. Jun 30; 28(2):8493. No abstract available.

19. Peters, A. (1970): The Fine Structure of the Nervous System. Pbl. Harper and Row Publishers, New York, U.S.A. PP.44-155.
20. Rotter A, Frostholm A. (1988): Cerebellar benzodiazepine receptors: cellular localization and consequences of neurological mutations in mice. Brain Res. Mar 15; 444(1):133-46.

21. Schaal H, Wille C, Wille W. (1985): Changes of ganglioside pattern during cerebellar development of normal and staggerer mice Neurochem. Aug; 45(2):544-51.

22. Schwartz RD, Jackson JA, Weigert D, Skolnick P, Paul SM. (1985): Characterization of barbiturate-stimulated chloride efflux from rat brain synaptoneurosomes. J Neurosci.Nov; 5(11):2963-70. 5-8.

23. Snell S. Richard (1997): Clinical Neuro anatomy for medical students, Fourth edition, Cha. 10, structure of the cerebellum page 303-315. Lippincott Williams \& Wilkins

24. Takeichi M.( 1983): Neurobiological studies of experimental diphenylhydantoin intoxication--III. Electron microscopic studies on development and disintegration mechanism of altered axon terminals and synaptic endings in rat cerebellum with chronic diphenylhydantoin intoxication. Folia Psychiatry Neurol Jpn; 37(4):455-64.

25. Vaccarino FM, Ghetti B, Wade SE, Rea MA, Aprison MH.(1983): Loss of Purkinje cell-associated benzodiazepine receptors spares a high affinity subpopulation: a study with pcd mutant mice. J Neurosci Res.; 9(3):311-23.

26. Valsecchi M, Palestini P, Chigorno V, Sonnino S, Tettamanti G. (1993): Changes in the ganglioside long-chain base composition of rat cerebellar granule cells during differentiation and aging in culture. J Neurochem. Jan; 60(1):193-6.

27. Vorhees CV, Rauch SL, Hitzemann RJ. (1990): Prenatal phenytoin exposure decreases neuronal membrane order in rat offspring hippocampus. Int $\mathbf{J}$ Dev Neurosci.; 8(3):283-8.

28. -Walsh iK, Schweitzer PK (1990): Ten year Trends in Pharmacological Treatment of insomnia sleep 22:371

29. -Westmoreland B, Bass NH.(1971): Diphenylhydantoin intoxication during pregnancy. A chemical study of drug distribution in the albino rat. Arch Neurol. Feb;24(2):158-64. No abstract available.

30. William L. Peter (1995): Gray's Anatomy, thirty edition chap. 8 nervous system cerebellum. Page, 1027-1065. Churchill Livingstone, New York, Edinburgh, London, Tokyo, Madrid and Melbourne, 
تأثير عقار - الديازيبام على نمو محتويات النسيج العصبي ( نيورويل )

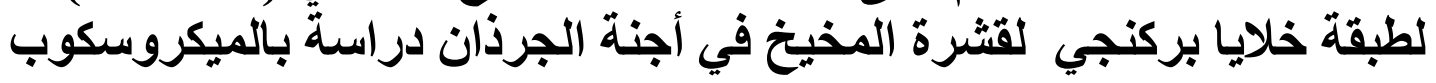
الإلكتروني

لطفي سيد**، ممدوح غالي**، عصام الدين عبد الهادي*، علا عبد الحميا *** وضائ

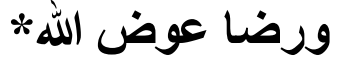

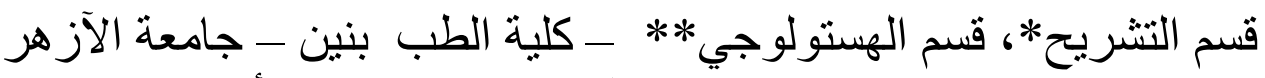

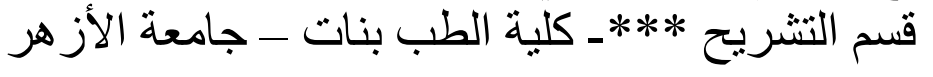

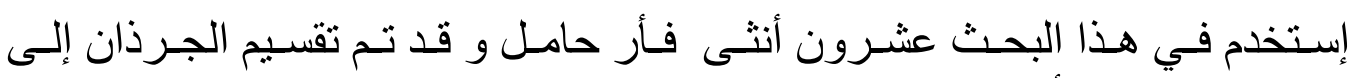

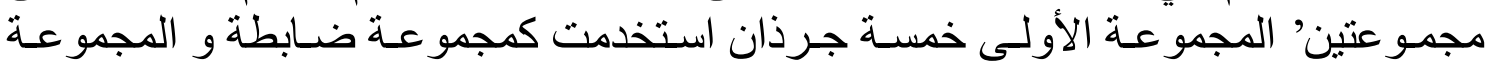

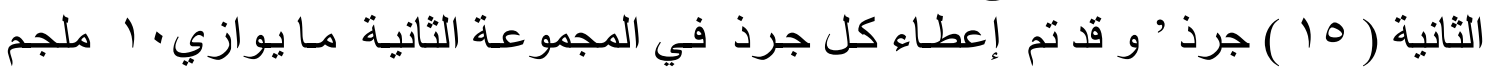

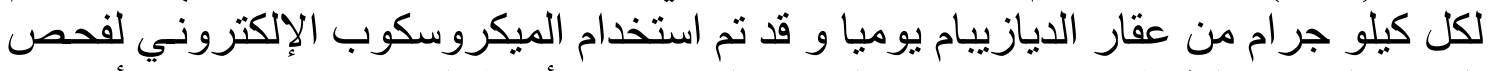

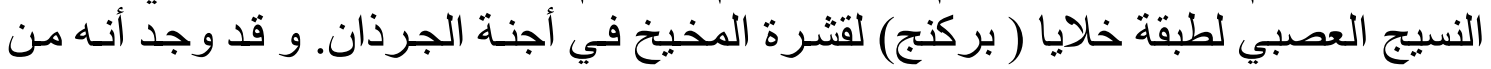

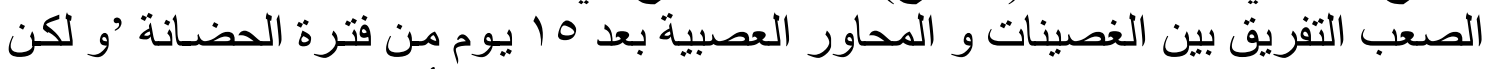

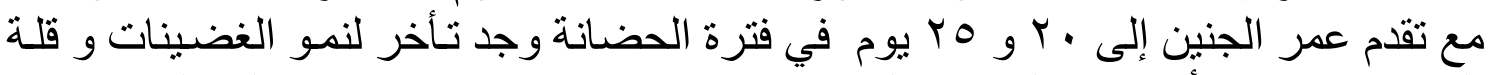

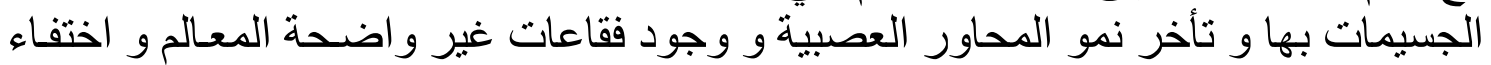

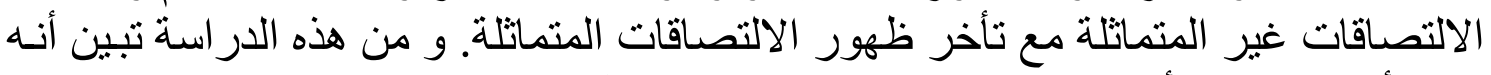
يجب أن تتحاثشى الأمهات الحو امل إستخدم المهئات طو ال فترة الحمل و خاصة في فئات الثهور الأولى. 